\title{
Biomedical waste handling and knowledge of its health hazards among waste handlers in a tertiary hospital in Sokoto, Nigeria
}

\author{
Umar Kaoje A. ${ }^{1}{ }^{*}$, Jega Garba . $^{2}$, Christina Okafoagu N. ${ }^{3}$, Olayinka Raji M. ${ }^{4}$, Mohammed Y. ${ }^{5}$, \\ Mohammed Ango U. ${ }^{6}$
}

DOI: https://doi.org/10.17511/ijphr.2018.i1.04

1* Aminu Umar Kaoje, Senior Lecturer, Department of Community Health, Usmanu Danfodiyo University, Sokoto, Nigeria.

2 Salihu Jega Garba, Department of Community Health, Usmanu Danfodiyo University, Sokoto, Nigeria.

${ }^{3}$ Nneka Christina Okafoagu, Lecturer, Department of Community Health, West Nile University, Abuja, Nigeria.

4 Mansur Olayinka Raji, Senior Lecturer, Department of Community Health, Usmanu Danfodiyo University, Sokoto, Nigeria.

5 Yahaya Mohammed, Senior Lecturer, Department of Medical Microbiology and Parasitology, Usmanu Danfodiyo University, Sokoto, Nigeria.

6 Umar Mohammed Ango, Lecturer, Department of Community Health, Usmanu Danfodiyo University, Sokoto, Nigeria.

Background: Biomedical wasteshave negative effects on human health and environment; therefore all persons exposed to the waste are potentially at risk, especially waste collectors that handle poorly segregated and containerized waste. The study aim was to describe the pattern of biomedical waste handling and assess knowledge of its health hazards among handlers in a Tertiary Hospital in Sokoto, Nigeria. Materials and Method: A descriptive cross-sectional study design was used. A total of 180 waste handlers were selected using a simple random sampling method and close-ended interviewer-administered questionnaires were used to collect data. Data was analyzed using SPSS version 23.0 and result presented in table. Results: Nearly half of the respondents were aged between $25-29$ years and majority $(81 \%)$ of the waste handlers are private employees while the public employees accounted for $19 \%$. Wastes from different unit of the hospital were poorly segregated and commonly collected using inappropriate containers without lining. Conclusion: Biomedical wastes from different units were poorly segregated and collected using inappropriate containers. Nearly all the respondents had good knowledge of its health hazards but only few (11\%) had received training on biomedical waste handling. Waste should be properly segregated into appropriate containers, PPE to be made readilyavailability and ensure compliance to their use.

Keywords: Biomedical waste, Handling, Knowledge, Risk perception

Corresponding Author

Aminu Umar Kaoje, Senior Lecturer, Department of Community Health, Usmanu Danfodiyo University, Sokoto, Nigeria.

Email: aukaoje@gmail.com
How to Cite this Article

To Browse

Kaoje AU, Garba SJ, Okafoagu NC, Raji MO, Mohammed Y, Ango UM. Biomedical waste handling and knowledge of its health hazards among waste handlers in a tertiary hospital in Sokoto, Nigeria. Public Health Rev Int J Public Health Res. 2018;5(1):26-34.

Available From

https://publichealth.medresearch.in/index.php/ijphr/ article/view/77
Manuscript Received 2018-02-26

Conflict of Interest No
Review Round 1 2018-03-07

Funding
Review Round 2 2018-03-16

Ethical Approval

Yes
Review Round 3

Plagiarism X-checker $7 \%$

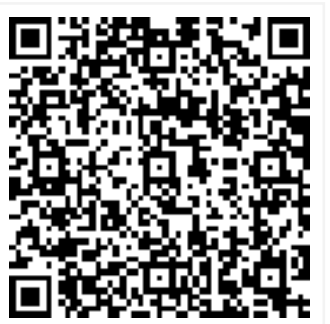

(c) 2018 by Aminu Umar Kaoje, Salihu Jega Garba, Nneka Christina Okafoagu, Mansur Olayinka Raji, Yahaya Mohammed, Umar Mohammed Ango and Published by Siddharth Health Research and Social Welfare Society. This is an Open Access article licensed under a Creative Commons Attribution 4.0 International License https://creativecommons.org/licenses/by/4.0/ unported [CC BY 4.0].

Accepted 2018-03-21

Note 


\section{Introduction}

Biomedical wastes are generated during the diagnosis, treatment, or immunization of human beings or in research activities pertaining to testing of biological sample [1]. Although all individuals exposed to hazardous health care waste are potentially at risk, the principal group at risk include health care providers, waste handlers, patients, visitors to healthcare facilities, workers in support service including laundry, and scavengers [2-4].

Hazards from infectious waste and sharps may spread Human immuno deficiency virus (HIV), hepatitis $B$ and $C$ virus, and other blood-borne pathogens. WHO estimated that each year there are about 8 to 16 million new cases of hepatitis B Virus (HBV), 2.3 to 4.7 million cases of hepatitis $C$ Virus (HCV) and 80,000 to 160,000 cases of HIV due to unsafe injection and mostly due to poor healthcare waste management system $[5,6]$. Lassa fever and Ebola virus, endemic in West Africa, havealso joined the league of blood borne pathogens.

Health facilities in Nigeria, have become source of dissemination of disease-causing materials, through the enormous quantities of improperly managed health care wastes being generated in the course of providing health services [7]. A study carried out in Jos, Nigeria showed that waste handling practice fell below waste management practices prescribed by WHO and other regulatory authorities as wastes were not segregated and were in appropriately disposed [8]. Proper waste handling helps to ensure appropriate hospital hygiene and safety of health care waste handlers, healthcare providers and communities at large [9]. The best practice is to segregate atsource intocolour coded containers for proper disposal as the waste poses high risk to the group [10].

All categories of health workers are exposed to the hazards of biomedical waste however, the level of exposure varies from one category of health workers to another and from one health facility to another within the same country. Of these categories, the waste handlers are the least educated as such their knowledge and risk perception of biomedical waste varies and such may affect their ability to use personal protective equipment as at when necessary. Characteristically, wastesare rarely segregated at the point of generation and inappropriately packaged and ultimately the waste handlers are expected to dispose this waste.
Because also of a desire to improve service delivery and productivity, waste handling and disposal is outsourced to private companies who in turn had to employ readily available manpower to provide the cleaning services.

It is on this background that the study is carried out to describe the pattern of biomedical waste handling and assess knowledge of its health hazards among handlers in a Tertiary Hospital in Sokoto, Nigeria. Theoutcome is expected to help the hospital management and managers of cleaning companies to make an informed decision about infection prevention and control.

\section{Materials and Methods}

Place of Study: The study was conducted in a tertiary hospital in Sokoto and study population comprised of all the biomedical waste handlers in the hospital both the public and private.

Type of Study: A descriptive cross-sectional study design was used and a required sample size was determined using formula for descriptive epidemiolo-gical study design for population less than ten thousand [11]. A sample size of 180 was obtained and all the number were enrolled into the study.

Sampling Method: A simple random sampling method (balloting technique) was used to select the study respondents. A 'yes' or 'No' option were written on pieces of papers and folded. This was rolled and a respondent asked to pick a paper from the pool. Any one that picked a piece of paper labelled 'yes' and having met the other inclusion criteria was enrolled into the study. This process continued until the required sample size of 180 respondents was selected.

Sample/ Data Collection: Field data was collected using questionnaire. The questionnaire was structured and contained close-ended questions. The questionnaire was pretested among waste handlers in different hospital that was not part of main study. Trained research assistants used faceto-face interview methods to collect the data.

Inclusion Criteria: Waste handlers involved in handling medical wastes generated during the process of diagnosis and patient/ client treatment including hospital environment; willing to participate in the study and present at the time of field data collection. 
Exclusion Criteria: Newly recruited waste handlers with less than a month waste handling experience were excluded.

Statistical Methods: The questionnaires were manually sorted out for completeness daily. Those questionnaires that were accurately filled and suitable for analysis were entered into computer and analyzed using statistical package for social science (SPSS) version 23.0.

Continuous data (respondents' age) was summarized using median and interquartile range while categorical data expressed in frequencies and percentage. Result was presented in simple tables for clarity.

Scoring and grading of responses on respondent' knowledge: Each correct response of knowledge question was scored 1 mark while zero (0) was awarded to wrong answers and or noresponse. The respondents' knowledge was graded as either good or poor knowledge. Knowledge score of less than $50 \%$ and equal to or greater than $50 \%$ was adjudged poor and good knowledge respectively.

At the end of scoring, the proportion of respondents with good and poor knowledge was determined. Continuous data were summarized using mean and standard deviation while the categorical and grouped data expressed in frequencies and percentages.

Ethical clearance was sought and obtained from the Usmanu Danfodiyo University Teaching Hospital (UDUTH) Research Ethics Committee. In addition, individual consent was also obtained from the respondent before the questionnaire was administered.

\section{Results}

Table 1 result showed that the median age of respondents was 35 years, Interquartile rage (IQR) of 28 - 44. There were more males, 54.4\% compared to females, $45.6 \%$ and a significant proportion (39.4\%) had only Qur'anic education, followed by those that had secondary education $(35.6 \%)$. Majority $(81 \%)$ of waste handlers were private employee while the remaining proportion $(18.9 \%)$ were public employees. With respect to trainings, only 20 out of 34 public employee received training about five years ago while none of the private employee have been formally trained.
Table-1: Socio and demographic characteristics of the waste handlers.

\begin{tabular}{|c|c|c|}
\hline Variables & Number & Percentage \\
\hline \multicolumn{3}{|l|}{ Age Group (Years) } \\
\hline $18-19$ & 6 & 3.4 \\
\hline $20-24$ & 18 & 10.0 \\
\hline $25-39$ & 86 & 47.8 \\
\hline $40-64$ & 70 & 38.9 \\
\hline \multicolumn{3}{|l|}{ Sex } \\
\hline Male & 98 & 54.4 \\
\hline Female & 82 & 45.6 \\
\hline \multicolumn{3}{|l|}{ Marital Status } \\
\hline Married & 119 & 66.1 \\
\hline Single & 32 & 17.8 \\
\hline Divorcee & 11 & 6.1 \\
\hline Widow & 18 & 10.0 \\
\hline \multicolumn{3}{|l|}{ Educational Level } \\
\hline Qur'anic & 71 & 39.4 \\
\hline Primary & 37 & 20.6 \\
\hline Secondary & 64 & 35.6 \\
\hline Tertiary & 8 & 4.4 \\
\hline \multicolumn{3}{|l|}{ Employment Status } \\
\hline Public & 34 & 18.9 \\
\hline Private & 146 & 81.1 \\
\hline \multicolumn{3}{|l|}{ Training } \\
\hline $\begin{array}{l}\text { Have you had any training on medical waste } \\
\text { handling since working in this facility? }\end{array}$ & 20 & 11.1 \\
\hline How long ago did you receive your last training? & & 5 years \\
\hline Number of public employee trained & 20 & 59 \\
\hline Number of private employee trained & 0 & 0 \\
\hline
\end{tabular}

Table-2: Knowledge of some aspects of biomedical waste Health hazards.

\begin{tabular}{|c|c|c|}
\hline Variables & Frequency & Percentage \\
\hline \multicolumn{3}{|c|}{ Knowledge of biomedical waste hazards } \\
\hline Good knowledge & 178 & 98.9 \\
\hline Poor knowledge & 2 & 1.1 \\
\hline \multicolumn{3}{|c|}{ Knowledge of some aspects of Healthcare waste hazard } \\
\hline \multicolumn{3}{|c|}{ Biomedical waste are generated while treating sick persons } \\
\hline Yes & 168 & 93.3 \\
\hline No & 12 & 6.7 \\
\hline \multicolumn{3}{|c|}{ Biomedical waste include: } \\
\hline \multicolumn{3}{|l|}{ Used needle syringe } \\
\hline Yes & 173 & 96.1 \\
\hline No & 7 & 3.9 \\
\hline \multicolumn{3}{|l|}{ Used cotton wool } \\
\hline Yes & 176 & 97.8 \\
\hline No & 4 & 2.2 \\
\hline \multicolumn{3}{|l|}{ Used injection bottles } \\
\hline Yes & 175 & 97.2 \\
\hline No & 5 & 2.8 \\
\hline
\end{tabular}




\begin{tabular}{|c|c|c|}
\hline \multicolumn{3}{|l|}{ Dead tissue from a wound } \\
\hline Yes & 151 & 83.9 \\
\hline No & 29 & 16.1 \\
\hline \multicolumn{3}{|l|}{ Expired drugs } \\
\hline Yes & 145 & 80.6 \\
\hline No & 35 & 19.4 \\
\hline \multicolumn{3}{|l|}{ Used I.V line/blood giving set } \\
\hline Yes & 177 & 98.3 \\
\hline No & 3 & 1.7 \\
\hline \multicolumn{3}{|c|}{ A person can get infected if in physical contact with these waste } \\
\hline Yes & 163 & 90.6 \\
\hline No & 17 & 9.5 \\
\hline \multicolumn{3}{|c|}{ Some diseases contacted through infected waste include: } \\
\hline \multicolumn{3}{|l|}{ Hepatitis B } \\
\hline Yes & 105 & 58.3 \\
\hline No & 19 & 10.6 \\
\hline Don't Know & 56 & 31.1 \\
\hline \multicolumn{3}{|l|}{ HIV infection } \\
\hline Yes & 132 & 73.3 \\
\hline No & 18 & 10.0 \\
\hline Don't Know & 30 & 16.7 \\
\hline \multicolumn{3}{|l|}{ Ebola Virus Disease } \\
\hline Yes & 112 & 62.2 \\
\hline No & 31 & 17.2 \\
\hline Don't Know & 37 & 20.6 \\
\hline \multicolumn{3}{|l|}{ Lassa fever } \\
\hline Yes & 69 & 38.3 \\
\hline No & 32 & 17.8 \\
\hline Don't Know & 79 & 43.9 \\
\hline \multicolumn{3}{|c|}{ Use of PPE reduce chance of contacting infection from waste } \\
\hline Yes & 177 & 98.3 \\
\hline No & 3 & 1.7 \\
\hline \multicolumn{3}{|l|}{ PPE appropriate for use by waste handlers includes } \\
\hline Face mask & 180 & 100 \\
\hline Eye goggles & 122 & 67.8 \\
\hline Hand gloves & 177 & 98.3 \\
\hline Rubber boots & 173 & 96.1 \\
\hline Plastic apron/uniform & 171 & 95.0 \\
\hline \multicolumn{3}{|l|}{ What part of body does each of these PPE protect? } \\
\hline Face mask: is to protect face (mouth and nose) & 179 & 99.4 \\
\hline Rubber boot is to protect the foot & 163 & 90.6 \\
\hline Hand gloves are to protect hands & 178 & 98.9 \\
\hline Eye goggle is to protect eyes & 34 & 18.9 \\
\hline Apron is to protect the body & 127 & 70.6 \\
\hline
\end{tabular}

Result in table 2 revealed that very large proportion ( $90 \%)$ of the respondents knew that biomedical wastes are generated when treating sick person and also different form of waste while $91 \%$ reported a person can get infected if in direct physical contact with infected waste.
Although a good number do not know whether some of the diseases conditions listed can be contacted from infected waste, nearly all of the respondents reported that use of personal protective equipment (PPE) may reduce the chance of coming in direct physical contact with the waste and contracting diseases.

Majority of respondents identified the appropriate PPE for use by waste handlers and also different part of body they protect.

Table 3 result showed that nearly all the respondents (99\%) feel it's very necessary to use personal protective equipment while handling hospital waste and $88 \%$ are willing to buy PPE on their own for personal use if not provided by the employer. Majority (98.3\%) also reported that it is good to wash hands with soap and water at the end of the day work.

Table-3: Waste handlers' attitude to waste handling and risk perception of the waste hazards.

\begin{tabular}{|c|c|c|}
\hline Variables & Frequency & Percentage \\
\hline \multicolumn{3}{|l|}{ Attitude to waste handling } \\
\hline \multicolumn{3}{|c|}{$\begin{array}{l}\text { It is necessary to use personal protective equipment while handling } \\
\text { hospital waste }\end{array}$} \\
\hline Yes & 178 & 98.9 \\
\hline No & 2 & 1.1 \\
\hline \multicolumn{3}{|c|}{$\begin{array}{l}\text { Will you advise your colleagues to always wear their PPE while working in } \\
\text { the hospital }\end{array}$} \\
\hline Yes & 176 & 97.8 \\
\hline No & 4 & 2.2 \\
\hline \multicolumn{3}{|c|}{$\begin{array}{l}\text { Are you willing to buy PPE with your own money for your personal use if } \\
\text { not provided by your employer }\end{array}$} \\
\hline Yes & 159 & 88.3 \\
\hline No & 21 & 11.7 \\
\hline \multicolumn{3}{|c|}{ It is good to wash hands with soap and water at the end of the day work } \\
\hline Yes & 177 & 98.3 \\
\hline No & 3 & 1.7 \\
\hline \multicolumn{3}{|l|}{ Risk perception of the waste hazards } \\
\hline $\begin{array}{l}\text { Waste handlers are at increased risk of injuries } \\
\text { and infections from the healthcare waste }\end{array}$ & 172 & 95.6 \\
\hline $\begin{array}{l}\text { Poorly disposed infected waste can be a source } \\
\text { of diseases outbreak }\end{array}$ & 179 & 99.4 \\
\hline $\begin{array}{l}\text { Proper segregation at the point of waste } \\
\text { production, help reduce the risk of exposure to } \\
\text { contaminated materials }\end{array}$ & 170 & 94.4 \\
\hline $\begin{array}{l}\text { Sharp biomedical waste like used needles \& } \\
\text { syringes, broken bottles, used surgical blades } \\
\text { carry more risk of injury }\end{array}$ & 175 & 97.2 \\
\hline
\end{tabular}


Kaoje A.U. et al: Biomedical waste handling and knowledge

\begin{tabular}{|l|l|l|}
\hline $\begin{array}{l}\text { Materials contaminated with patient body fluid like } \\
\text { blood, urine should be considered infectious } \\
\text { regardless of patient diagnosis? }\end{array}$ & 175 & 97.2 \\
\hline $\begin{array}{l}\text { Waste handlers if not properly protected, can be } \\
\text { infected and also transfer infectious agent to their } \\
\text { family members at home }\end{array}$ & 173 & 96.1 \\
\hline $\begin{array}{l}\text { Hospital acquired infectious agent are usually drug } \\
\text { resistance and their infection could be fatal }\end{array}$ & 143 & 79.4 \\
\hline
\end{tabular}

Respondents' perception of risk is high as $96 \%$ perceived that the handlers are at increased risk of injuries and infections from the contaminated waste and that sharp biomedical waste like used needles \& syringes, broken bottles, used surgical blades carry more risk of injury and infection (97\%).

Proper segregation of waste at the point of production is perceived by majority of respondents' (94\%) to help reduce the risk of exposure to contaminated materials and that if handlers are not properly protected, can be infected and also transfer infectious agent to their family members at home.

Table 4 results revealed that all the respondents reported the use of PPE while handling biomedical waste but only $19 \%$ of them were found to use appropriate PPE during work through inspection aspect of the survey. Most reported PPE to be used always was facemask by $73 \%$ of respondents followed by hand gloves (65\%), and 56\% wear their uniform while none had ever used plastic apron.

Table-4: Practice of occupational safety by biomedical waste handlers

\begin{tabular}{|c|c|c|}
\hline Variables & \multicolumn{2}{|c|}{ Frequency| Percentage } \\
\hline \multicolumn{3}{|c|}{$\begin{array}{l}\text { Do you wear Personal protective equipment while handling waste in the } \\
\text { hospital }\end{array}$} \\
\hline Yes & 180 & 100 \\
\hline No & 0 & 0 \\
\hline \multicolumn{3}{|c|}{ If yes, how often do you use these Personal protective equipment: } \\
\hline \multicolumn{3}{|l|}{ Face mask } \\
\hline Always & 132 & 73.3 \\
\hline Most times & 41 & 22.8 \\
\hline Occasionally & 7 & 3.9 \\
\hline \multicolumn{3}{|l|}{ Eye goggles } \\
\hline Always & 8 & 4.4 \\
\hline Most times & 16 & 8.9 \\
\hline Occasionally & 156 & 86.7 \\
\hline \multicolumn{3}{|l|}{ Hand gloves } \\
\hline Always & 117 & 65.0 \\
\hline Most times & 31 & 17.2 \\
\hline Occasionally & 32 & 17.8 \\
\hline \multicolumn{3}{|l|}{ Rubber boots } \\
\hline Always & 81 & 45.0 \\
\hline
\end{tabular}

\begin{tabular}{|l|c|c|c|}
\hline Most times & 29 & 16.1 \\
\hline Occasionally & 69 & 38.3 \\
\hline Uniform & 101 & 56.4 \\
\hline Always & 13 & 7.3 \\
\hline Most times & 65 & 36.3 \\
\hline Occasionally & \multicolumn{3}{|l|}{} \\
\hline Waste handler practice of occupational safety & 35 & 19.4 \\
\hline Use appropriate Personal protective equipment (PPE) always & 145 & 80.6 \\
\hline Use PPEs most times or occasionally & \multicolumn{3}{|l|}{} \\
\hline
\end{tabular}

Findings from work through inspection at different areas of the hospital revealed that appropriate receptacles for different categories of waste collection were not available and largely improvised particularly for the sharps. Wastes were poorly segregated, as mixture of all kind of waste in one receptacle is a common finding.

Loose sharps inside and outside the wards, clinics including overflowing sharp box are seen during the work through inspection of different units in the hospital. Waste is transported from these service points to temporary dumpsites commonly with plastic containers without cover while few uses wheeler bins.

\section{Discussion}

Biomedical waste (BMW) carries a high potential of infection and injury than any other type of waste and it is important that waste handlers should have proper knowledge and practice of handling and disposal of these wastes [12]. Almost all the respondents in the study had overall good knowledge of biomedical waste hazards.

Although a good proportion of the waste handlers had only quar'anic level of education, they still exhibited good knowledge. This very likely to be attributed to their interaction with trained health worker who informally provide them with some information on best practices about health care waste.

This is unlike studies in India that showed inadequate knowledge of biomedical waste among the waste handlers [12 - 13]. The study demonstrated that majority of the respondents knew the sources of BMW. This is in tandem with studies carried out in Agartala and in Central India, which found that most of the respondents answered correctly about the sources of BMW [14-15].

In this study, most of the respondents did not have the knowledge that exposure to BMW, there were chances of transmission of HIV, hepatitis, 
Lassa fever and Ebola virus disease. This is not surprising, as most of the respondents had not been trained on biomedical waste handling and so, this deficiency in knowledge is expected.

Their lack of knowledge could predispose them to increased risk of theseblood - borne infectious diseases which could be potentially life threatening. This finding concurs with similar studies in India that demonstrated that only few sanitary workers had knowledge regarding the potential transmission of disease on exposure to BMW $[12,16]$.

Regarding attitude towards BMW, most of the respondents felt that proper segregation at the point of waste production could help reduce the risk of exposure to contaminated materials. This same perception was shared by participants in similar studies in India $[13,14]$. Segregation of BMW at the point of generation has been described as one of the first five steps in proper healthcare waste management [17].

All the respondents attested to wearing Personal protective equipment (PPE) while handling waste in the hospital although only very few used the appropriate PPE always. This finding is disheartening as one of the requirements for avoiding the prevalence of workplace hazards is the use of protective equipment to avoid direct contamination [18].

Though most of the respondents in this study knew the PPE appropriate for use by waste handlers, it is evident that their knowledge did not translate to practice as only few used the appropriate PPE always.

However, non-availability of PPE / insufficient PPE in the hospital could be the reason why the respondents did not utilize appropriate PPE always. A study carried out in Karnataka, India reported that only about a third of the waste handlers used PPE [13] and in another similar study in Bangladesh, respondents identified insufficient PPE in the hospital as a possible barrier to biomedical waste management

Every worker deserves protection from hazardous wastes to live a healthy life, therefore, biomedical health facility must provide or purchase PPE and also educate their employees on the importance of always using PPE while handling BMW [20].

\section{Conclusion}

Although significantly large proportion of respondents demonstrated good knowledge of the health hazard of biomedical waste, equally very large number of them does not use this personal protective equipment as revealed by work through survey. These have serious implication for the control of nosocomial infection and prevention of spread nosocomial microorganism through person to person.

All these on a background of lack of appropriate receptacles for different categories of waste collection in different areas of the hospital and were largely improvised particularly for the sharps. Wastes were also poorly segregated, as mixture of all kind of waste in one receptacle is a common finding.

Contribution to knowledge: This study was able to document the actual situation of waste handling and collection and serious implication for potential nosocomial infection in the health facility. In spite of the global and national efforts toward sanitary health care waste management and tertiary nature of the hospital with respect to service delivery, rudimentary methods of waste handling and collections are still in practice and health workers exposed to the danger of physical contact with biomedical waste.

\section{Authors Contribution}

Aminu Umar Kaoje: Conceptualized the study and developed the study proposal including questionnaires

Salihu Jega Garba: Contributed significantly in the proposal development and filed data collection coordination

Nneka Christina Okafoagu: Wrote the entire discussion and conclusion sections of the article

Mansur Olayinka Raji: Conducted the data analysis and description of the finding (result section)

Yahaya Mohammed: Harmonized the entire document and also coordinated field data collection

Umar Mohammed Ango: Coordination of field data collection and report writing 


\section{Acknowledgements}

Authors hereby acknowledge the full cooperation of the management of the tertiary institution where study was conducted and also the research assistants that ensured quality assurance throughout the process of data collection.

\section{Reference}

01. Sharma AK. Bio-medical waste management and handling Rules. Suvidha Law House, Bhopal. 1998.

[Crossref]

02. National Institute for occupational safety and health (NIOSH). Preventing occupational exposure to antineo-plastic and other hazardous drugs in health care settings. [Crossref]

03. Habibullah J, Ahmad K, and Khan MA. Managing the healthcare solid waste in selected districts of Punjab, Pakistan. Pak J Med Sci. 2010,26(4)795-799.

[Crossref]

04. World Health Organization. Management of was te from injection activities at the district levelguidelines for district health managers. Geneva, Switzerland- World Health Organization. 2006. [Crossref]

05. World Health Organization. Unsafe injection practices and transmission of blood borne pathogens. Bull, World Health Organization. $1999 ; 77 ; 787-819$.

[Crossref]

06. Townend WK, Cheeseman CR. Guidelines for the evaluation and assessment of the sustainable use of resources and of wastes management at healthcare facilities. Waste Manag Res. 2005 Oct;23(5)398-408.

[Crossref]

07. Akinwale C, Sridhar MKC. Increase in healthcare facilities and rapid environmental degradation, $A$ technical paradox in Nigeria's urban centers. Afr J Environ Sci Technol. 2010;4 (9)577-85. [Crossref]

08. Ngwuluka N, Ochekpe N, Odumosu P, John SA. Waste management in healthcare establishments with in Jos metropolis, Nigeria. Africa Journal of Environ-mental Science and Technology. 2009;3(12)459-465.

[Crossref]
09. Pasupathi P et al. Biomedical Waste Management for health care industry. International Journal of Biological and Medical Research. 2011;2(1)472-86.

[Crossref]

10. Sood AG, Sood A. Dental perspective on biomedical waste and mercury management- a knowledge, attitude, and practice survey. Indian J Dent Res. 2011May-Jun;22(3)371-5. doi:10.4103/0970-9290.87055 [Crossref]

11. Kirkwood RB and Jonathan AC. Essential Medical Statistics. Massachusetts, USA, Blackwell Publishing Ltd. 2nd Edition.

2003;423 [Crossref]

12. Mathur V, Dwivedi S, Hassan M, Misra R. Knowledge, Attitude, and Practices about Biomedical Waste Management among Healthcare Personnel- A Cross-sectional Study. Indian J Community Med. 2011 Apr;36(2)143-5. doi: 10.4103/0970-0218.84135 [Crossref]

13. Imaad Mohammed Ismail, Annarao G Kulkarni, Suchith V Kamble, Sagar A Borker, Reka R and Amruth M. Knowledge, attitude and practice about bio-medical waste management among personnel of a tertiary health care institute in Dakshina Kannada, Karnataka. Al Ameen J Med Sci. 2013;6(4)376-380.

[Crossref]

14. Nabarun Karmakar, Shib Sekhar Datta, Anjan Datta, Kaushik Nag, Kaushik Tripura, Partha. A cross-sectional study on knowledge, attitude and practice of biomedical waste management by health care personnel in a tertiary care hospital of Agartala, Tripura. National Journal of Research in Community Medicine. 2016;5(3)189-195.

[Crossref]

15. ShashwatiNema, Akansha Singh, Kiran Tripathi, Pallavi Shidhaye, Ashok Kumar Dhanvijay. Biomedical Waste Management- A Study of Knowledge, Practices and Attitude among Health Care Personnel at a Tertiary Care Hospital in Bhopal, Central India. JMSCR. 2015;3(5)58445855.

[Crossref] 
16. S Sangeetha Balamurugan, Priyadarsini SP, Renusha Justin, Rupa Priyadarshini Sonai, Rajeswari B, Ramit Chakraborty. A Descriptive Study on Knowledge Regarding Biomedical Waste Management among Health Care Personnel in a Tertiary Care Hospital. National Journal of Research in Community Medicine. 2014;3(2)186-191.

[Crossref]

17. Patil GV, Pokhrel K. Biomedical solid waste management in an Indian hospital- a case study. Waste Manag. 2005;25(6)592-9.

[Crossref]

18. Lehtinen L. Occupational Health and Safety. African Newsletter on Occupational Health and Safety. 2002;12;32-34.

[Crossref]
19. Mohammad Abul Bashar Sarker, Harun-OrRashid, Tomoya Hirosawa, Shaheen Bin Abdul Hai, Ruhul Furkan Siddique, Junichi Sakamoto, Nobuyuki Hamajima. Evaluation of Knowledge, Practices, and Possible Barriers among Healthcare Providers regarding Medical Waste Management in Dhaka, Bangladesh. Med Sci Monit. $2014 ; 20 ; 2590-2597$.

[Crossref]

20. Mburu Moses, Nguthu Gikunju, Joseph K, Onguso M, Justus Wakibia Joseph. Occupational Safety and Health Accidents among Biomedical Waste Handlers in Nairobi County. Journal of Environment and Earth Science. 2016;6 10)817.

[Crossref] 